Victoria de Grazia

\title{
KINO EUROPEJSKIE I IDEA EUROPY 1925-1995
}

\section{Kino i tożsamość europejska}

Rok 1995 obchodzony był jako stulecie kina europejskiego. Za jego początek uznano rok 1895 - paryską premierę kinematografu braci Lumière, pierwszego opatentowanego urządzenia rejestrującego, kopiującego i wyświetlającego film. Obchody rocznic służą na ogół konstruowaniu rodowodów, określaniu granic włączania lub wykluczania oraz organizowaniu dziedzictwa, wobec którego proweniencji mogą istnieć pewne wątpliwości. Uroczystości te stały się szczególnie istotne $\mathrm{w}$ czasach polityki tożsamości ${ }^{1}$, a wspomniana rocznica nie jest wyjątkiem. Choć nie tak kontrowersyjna jak inne jej podobne (ot, choćby dwóchsetlecie rewolucji francuskiej lub pompatyczne celebrowanie sześćsetlecia bitwy o Kosowo przez Serbów), również buduje genealogię i niesie określone przesłanie ${ }^{2}$. Warto zauważyć, że Festiwal Filmowy w Wenecji, który uczcił to wydarzenie, pokazując sto filmów europejskich, jest też pierwszym festiwalem filmowym Starego Kontynentu. Gdy w 1934 roku przy silnym poparciu reżimu faszystowskiego zorganizowano go po raz pierwszy, głównym celem była promocja renesansu europejskiego przemysłu filmowego jako alternatywy dla kina hollywoodzkiego.

1 Zob. Commemoration and the Politics of National Identity, ed. J. Gillis, Princeton University Press: Princeton 1994.

2 Już sama decyzja, którą rocznicę z dziejów kinematografii celebrować, była poważnym wyzwaniem. Odzwierciedlała nie tyle dylematy badawcze dotyczące sekwencji wydarzeń, ile rywalizację o „palmę pierwszeństwa” między Amerykanami i Europejczykami. Wyścig zaczął się zresztą już wcześniej, wraz z ogłoszeniem pierwszej „setnej rocznicy" - nie kina, lecz taśmy filmowej - przez Eastman Kodak (firmy nie zraziło to, że w tamtych czasach nie było kina, w którym można ją było wyświetlić...). Następnie celebrowano poszczególne etapy prac Edisona: pierwszy patent, pierwszy działający kinetograf, pierwszy pokaz kinetoskopu w Nowym Jorku - wszystkie przed 1895 rokiem. Interpretacja europejska (z którą zgadza się również wielu amerykańskich badaczy) mówi jednak o tym, że nic z tego, co robił Edison i jemu podobni przed rokiem 1895, nie było właściwym „kinem”, oznacza ono bowiem nie tylko ruchome obrazy, ale też proces publicznej projekcji. 
Odwoływanie się do Europy lub do idei przynależności do cywilizacji europejskiej z reguły jest częstsze, gdy Europejczycy stają w obliczu kryzysu. Czasy współczesne, pełne eurosceptycyzmu oraz krytyki eurokratów wraz z obroną europejskiej przestrzeni kulturowej - a konkretnie sfery audiowizualnej i filmowej - nie są wyjątkiem. „J'entends parler d'Europe, la guerre n'est pas loin” („Styszę, że mówi się o Europie - to znaczy, że wojna jest bliska”) - brzmiała uwaga, którą François Perroux (wybitny francuski ekonomista polityczny) usłyszał od swojego przyjaciela w 1954 roku, gdy powiedział mu, że właśnie skończył pisać książkę na temat jedności Europy. Przenikliwe (i ciągle aktualne) dzieło nosiło tytuł L'Europe sans rivages (Europa bez brzegów) i poświęcone było analizie siły przemysłu i handlu wielkich europejskich państw narodowych, w szczególności Francji i Niemiec, które, za czasów Napoleona, a następnie Hitlera, w swoich katastrofalnych i skazanych na klęskę wysiłkach odwoływały się do idei zjednoczonej Europy, by legitymizować swoje dążenia do hegemonii³

Najnowszy renesans idei Europy, w kontekście którego obchodzone jest stulecie europejskiego kina, stoi w kontrze do wspomnianych katastrofalnych doświadczeń unifikacji i rozłamu. Obecna debata o kondycji kontynentu, podobnie jak w pierwszej połowie stulecia, nieuchronnie sugeruje wysokość stawki. Czy Europa będzie duża czy mała, zamknięta czy otwarta, biurokratyczna czy zdecentralizowana, zachodnia czy transkontynentalna? Czy będzie zjednoczona jedynie ekonomicznie i politycznie, czy także kulturowo? Znacznie mniej niż od zdefiniowania charakterystycznych dla niego cech, kino europejskie i jego istnienie jako kategorii zależy właśnie od powyższej, szerszej perspektywy. Czy etykieta „europejski” powinna stosować się tylko do produktów wytworzonych na terytorium Europy i przy udziale europejskiego kapitału? Czy może też powinna odwoływać się do dzieł reżyserów pochodzących z krajów europejskich, nawet jeśli finansowane były przez inwestorów innych niż europejscy? Czy sugeruje jakość twórczej ekspresji albo artystyczną tradycję, wyrażając niejako estetykę danej kultury? Jeśli istnieje kino europejskie, to czy jego „innym” jest kino amerykańskie, a konkretnie Hollywood? Jeśli przyjmiemy perspektywę globalną, to czy przypadkiem kino europejskie nie byłoby w jakiś sposób połączone z ideą Zachodu, w opozycji do kina „Wschodu” albo kina kolonialnego? Czy powinno znajdować się w opozycji do kina afrykańskiego, południowoamerykańskiego, indyjskiego czy azjatyckiego? Wreszcie, jeśli istnieje kino europejskie, jakie są jego związki z kinematografiami "narodowymi”, jakie elementy łączą, przykładowo, kino artystyczne z produkcją komercyjną, filmy eskapistyczne z dziełami propagandowymi, żeby można było stworzyć z nich jeden, specyficznie europejski amalgamat? ${ }^{4}$

3 F. Perraux, L’Europe sans rivages, Presses Universitaires de France: Paris 1955, s. 15.

4 Europejscy badacze kultury popularnej i mediów znacząco przyłożyli się do debaty o amerykanizacji i związkach między lokalnym, narodowym, transeuropejskim 
Poszukiwanie odpowiedzi na te pytania ma długą historię. Zaczyna się ona w Europie po zakończeniu Wielkiej Wojny, gdy rządy, przywódcy, intelektualiści oraz (w różnym stopniu) publika kinowa zareagowali na szerokie możliwości nowego przemysłu oraz na wyzwanie rzucone przez produkcje hollywoodzkie ${ }^{5}$. Choć wpływ konkurencji ze strony Stanów Zjednoczonych na poszczególne państwa europejskie był bardzo różnorodny, a krajowe przemysły filmowe nie były jeszcze postrzegane jako "narodowe” ani jednolite w swych strategiach biznesowych, intelektualiści natychmiast określili, wynikającą z napływu amerykańskich produkcji, zmianę warunków gry handlowej jako początek walki na śmierć i życie między dwiema cywilizacjami ${ }^{6}$. W latach międzywojennych transeuropejskie

i globalnym. Zob. publikacje redagowane przez R. Kroesa i in., zwłaszcza Cultural Transmissions and Receptions: American Mass Culture in Europe, VU Press: Amsterdam 1993. Ważne materiały znajdują się również w podręczniku wydanym z okazji konferencji zorganizowanej w październiku 1994 roku: GATT, the Arts, and Cultural Exchange between United States and Europe, ed. A. van Hemel. Można również wskazać teksty P. Schlesingera, zwłaszcza On National Identity: Some Conceptions and Misconceptions Criticized, „Social Science Information” 1987, Vol. 26, No. 2, s. 219-264. Artykuł G. Rochu Marché commun contre Hollywood, „Libération” 1992, 12 May, prezentuje klarowną ocenę trudności w stosowaniu terminu „europejski” w opozycji do „amerykański”. Autor zauważa, że filmy takie jak Zamek pułapka (Le Diable par la queue, 1969) De Broca czy Mitość Adeli H. (L'Histoire d'Adèle H., 1975) Truffauta zostały wyprodukowane przy udziale amerykańskiego kapitału. Na temat koncepcji "kina narodowego” zob. T. Elsaesser, Holland to Hollywood and Back: or Do We Need a National Cinema?, [w:] De onmacht van het grote: cultuur in Europa, eds. J. C. H. Bloom, J. Th. Leerssen, P. de Rooy, Amsterdam University Press: Amsterdam 1993, s. 81-95.

${ }^{5} \mathrm{Na}$ temat szerokiego zasięgu amerykańskiej ekspansji zagranicznej zob. I. Jarvie, Hollywood's Overseas Campaign: The North Atlantic Movie Trade, 1920-1950, Cambridge University Press: Cambridge 1992, oraz K. Thompson, Exporting Entertainment, British Film Institute: London 1985. Badania na temat wplywu na kinematografie europejskie zob. V. de Grazia, Sovereignty and the Star System: the American Challenge to the European Cinemas, 1920-1960, „Journal of Modern History” 1989, Vol. 61, No. 1, s. 53-87, oraz doskonałą analizę T. Saundersa, Hollywood in Berlin: American Cinema and Weimar, University of California Press: Berkeley 1994.

${ }^{6}$ Pierwszy International Motion Picture Congress został zorganizowany w Paryżu, w dniach 27 września- 2 października 1926 roku, i odbywał się pod auspicjami International Institute of Intellectual Co-operation. Jego celem było wypracowanie międzynarodowych standardów pod przywództwem „bloku europejskiego”. Wspomniany instytut był agendą Ligii Narodów, do której USA nie przynależało. Tym samym Stany Zjednoczone i amerykański handel byly zupełnie nieobecne w trakcie kongresu (przynajmniej częściowo z powodu zwerbalizowanego przez dyrektora generalnego Ufy: żaden biznesmen nie mógł sobie wtedy pozwolić - bez naprawdę ważnego powodu - na czterotygodniowy przyjazd do Europy). Czołowe europejskie gazety handlowe były krytycznie 
sojusze, tworzone by stawić czoła ekonomicznemu „wrogowi” i kulturowemu „obcemu”, okazały się ulotne. Te, które rozwinęły się pod przywództwem potężnego przemysłu niemieckiego, zostały ostatecznie podporządkowane agresywnemu ekspansjonizmowi Niemiec.

W przeciwieństwie do tamtego okresu, po II wojnie światowej dążenie do europejskiego zjednoczenia definiowane było przede wszystkim pod względem ekonomicznym. Poszukiwanie wspólnej tożsamości kulturowej było w Europie Zachodniej celem drugorzędnym. Porozumienia zawarte w ramach Europejskiej Wspólnoty Gospodarczej w 1957 roku nie zawierały ani słowa o wspólnej, europejskiej kulturze ani o wspieraniu kina jako dziedziny przemysłu (pierwsza dyrektywa dotycząca tego ostatniego pochodzi z 1963 roku) ${ }^{7}$. Dopiero niedawno w wyniku traktatu z Maastricht i dalszej konsolidacji Unii Europejskiej potrzeba definiowania Europy przez wspólną tożsamość kulturową znalazła oddźwięk. Kwestia ta, zrodzona $\mathrm{z}$ dysput na temat zakresu i natury zjednoczenia, jak również w reakcji na nową, ogromną presję amerykańskich przedsiębiorstw medialnych, skupiła uwagę na losie europejskiej przestrzeni audiowizualnej. Wszystko to składa się na szerszy kontekst obchodów stulecia kina europejskiego.

Zamierzam prześledzić genealogię idei „kina europejskiego”, koncentrując się na dwóch momentach europejskiej historii, gdy termin ten został przywołany jako odpowiedź nie tylko na kryzys przemysłu jako takiego, ale również na kryzys tożsamości kulturowej. Wynikał on z wewnątrznarodowych konfliktów, które z kolei były skutkiem nowego miejsca Europy na rynkach światowych. Problem obrony „narodowych” rynków i kultury, najpierw w latach 30. nazistowskiego Nowego Porządku, następnie w latach 60., czyli w czasach budowania tzw. „Europy narodów” pod zwierzchnictwem amerykańskiego hegemona, został przekształcony w kwestię „obrony Europy”, choć przy użyciu innych środków. Jestem tu szczególnie zainteresowana rozbieżnością między nacjonalizmem i europeizmem, czego konsekwencją było funkcjonowanie pojęcia „Europa” i „europejskość" jako odwołania do nacjonalistycznej tożsamości, celem utrzymania wielkoformatowych interesów poszczególnych sektorów gospodarki, wzmocnie-

nastawione do kongresu, traktując całe przedsięwzięcie jako zdominowane przez intelektualistów (wśród nich był „London Renter and Moving Picture News”, gdzie napisano: „Przemówienia w niejasny sposób tłumaczyły, co chciano zrobić z kinem, i byly pełne zwyczajowych nonsensów na temat podnoszenia moralnych i intelektualnych standardów kinematografii"), zwracały uwagę, że z racji na dominującą pozycję Stanów Zjednoczonych w przemyśle filmowym, żadne takie zgromadzenie nie będzie efektywne bez udziału ich przedstawicieli. Zob. National Archives, Department of Commerce, Bureau of Foreign and Domestic Trade, F. 151, France, 4, October-December 1926. Report G. Canty, 12 October 1926.

7 T. H. Guback, Cultural Identity and Film in the European Economic Community, „Cinema Journal” 1974, Vol. XIV, No. 1, s. 2-17. 
nia solidarności etnicznej i narodowej oraz ograniczenia partykularyzmów kulturowych. Analiza definicji „Europy”, pojawiających się w tych dwóch momentach, gdy odpowiadano na wyzwanie rzucone przez Stany Zjednoczone (które same uległy znaczącym przemianom), podkreśla trudności, jakie europejskie przedsiębiorstwa kulturowe i komunikacyjne miały w pogodzeniu interesów lokalnych z narodowymi i ponadnarodowymi oraz w poszukiwaniu wspólnych strategii. Niniejsze studium wskazuje również na przemiany w przypisywaniu kulturze filmowej sposobu wpływania na budowanie narodowych i europejskich tożsamości. Na przykład, w latach 30. kino - wyłączając jego oczywistą funkcję rozrywkową i komercyjną - traktowano jako narzędzie państwowej propagandy i główny masowy środek przekazu dla narodowej estetyki. W latach 60. film odzwierciedlał energię w odbudowywaniu Europy i koncentrację Europy Zachodniej na wspólnym, wysokim standardzie konsumpcji. Dziś wkład przemysłu filmowego $\mathrm{w}$ lokalne gospodarki w zakresie zatrudnienia oraz produktu krajowego brutto jest o wiele mniejszy niż kiedyś i prezentuje się skromnie na tle potęgi i zysków sektora informacyjnego. Niemniej wkład kina w kulturę narodową zyskał istotne znaczenie - tak duże, iż argumenty dotyczące obrony kinematografii europejskiej zasadzają się na traktowaniu kina nie jako produktu komercyjnego, tylko jako prawdziwego pomnika kultury wysokiej, na równi z operą, orkiestrami symfonicznymi lub dziełami malarskimi wielkich mistrzów. Jednocześnie kinematografię uznaje się za artefakt popularnych subkultur, niezbędny w kształtowaniu wielokulturowej tożsamości w ramach „europejskiej ojczyzny”, rozciągającej się od Atlantyku aż po Ural.

Aby poddać analizie poszczególne definicje europejskości i kina europejskiego, przejdziemy od czasów recesji, przez kapitalistyczny Złoty Wiek, aż do dzisiejszej Europy, rozdartej między procesami zjednoczenia regionalnego i świeżo narastającymi lokalizmami, transglobalnymi prądami oraz przyciąganiem ze wschodu i południa w kierunku Rosji i Bałkanów. W latach 30. europejski system państwowy, nigdy do końca nie odbudowany po Wielkiej Wojnie, znajdował się w kryzysie. Samozwańczym czempionem jego odrodzenia były nazistowkie Niemcy: proponowały one, obejmujący cały kontynent, zamknięty, zdominowany przez Niemców rynek (Grosswirtschaftsraum). Ich kulturowym postulatem było ustanowienie „Europy duchowej” na drodze oczyszczenia przestrzeni geopolitycznej z ,judeo-bolszewizmu”. Kino było uznawane w tym kontekście za główne narzędzie. Natomiast w latach 60 . roszczenie do wypowiadania się w imieniu Europy, podzielonej granicami zimnej wojny, było wysuwane w ramach wspólpracy wielkiej europejskiej Szóstki, której przewodziły Francja i Republika Federalna Niemiec. Motywacja towarzysząca politykom tworzącym wówczas europejskie regulacje była pragmatyczna, dyktowana chęcią rywalizacji ze Stanami Zjednoczonymi, przy jednoczesnym utrzymaniu ich ochrony militarnej i przywództwa ekonomicznego. Gdy idealistyczne wizje duchowej jedności zostały pokonane przez twarde zasady porozumień gospodarczych, polityczni 
decydenci wyobrazili sobie europejską tożsamość jako naturalny wynik połączenia poszczególnych państw na wspólnej drodze ku modernizacji. Była to idea silnie wspierana przez przekonania amerykańskich specjalistów od nauk społecznych o sposobie funkcjonowania procesów narodowej i kulturowej integracji, w których oddolne organizacje społeczne i wartości obywatelskie przesycone są - za sprawą wpływu masowej komunikacji - poczuciem narodowej misji ${ }^{8}$. Stosownie do niej rządy zaprojektowały rolę służby publicznej dla sektora kultury audiowizualnej. Do tego czasu rolę tę najlepiej odgrywała telewizja; wśród wielu zalet - w przeciwieństwie do kina - była możliwość wspierania jej przez rządowe monopole. To właśnie utrata wiary $\mathrm{w}$ dotychczas obowiązujący pogląd jakoby ujednolicony rynek wytwarzał równie ujednoliconą tożsamość kulturową, skutkującą podzielanym przez wszystkich poczuciem obywatelstwa, stanowi podłoże dzisiejszego powszechnego kryzysu „tożsamości”.

\section{Europa Nowego Ladu}

Niezdolność kinematografii europejskich do sprostania wyzwaniu rzuconemu przez USA w pierwszej połowie XX wieku wynikała, mówiąc wprost, $\mathrm{z}$ nieumiejętności przeformułowania się suwerennych i tradycyjnie zwaśnionych państw europejskich w regionalną siłę ekonomiczną. Taka skala operacji była niezbędne do stworzenia wspólnych strategii, będących w stanie odpowiedzieć na wymagania rynkowe i produkcyjne, których spełnienie było konieczne do odniesienia sukcesu w gospodarce światowej. Niektórzy pragmatycy - chociażby John Maynard Keynes, w 1919 roku przenikliwie piszący o katastrofalnych skutkach traktatu wersalskiego - stanowczo przekonywali, że nie będzie trwałego pokoju w Europie bez poszerzenia rynków narodowych i stworzenia międzynarodowych struktur mogących dostosować się do Niemiec, najpotężniejszej gospodarki kontynentu'. Wplywowy wizjoner, Erich Pommer, szef produkcji w Ufie w okresie Republiki Weimarskiej, mógł wyobrazić sobie działanie na skalę całego regionu. Już w 1925 roku, jeszcze przed swoim pobytem w Hollywood, Pommer popierał tworzenie „filmów europejskich, które nie byłyby już francuskie, angielskie, włoskie czy niemieckie, ale kontynentalne”, przez co rozumiał „dzieła szybkiej i szerokiej europejskiej dyfuzji, która pozwoliłaby na amortyzację zbyt wysokich

${ }^{8}$ Na temat kultury obywatelskiej, wpływu mediów oraz integracji społecznej zob.: G. Almond, S. Verba, The Civic Culture, Princeton University Press: Princeton 1963; National Building and Citizenship, ed. R. Bendix, John Wiley and Sons: New York 1964; K. Deutsch, Nationalism and Social Communication, $2^{\text {nd }}$ ed., MIT Press: Cambridge 1966.

9 J. M. Keynes, The Economic Consequences of the Peace, Harper and Row: New York 1971. Tę samą tezę lansował mocno Perroux. 
gdzie indziej kosztów"10. Jednak dla każdego europejskiego przedsiębiorstwa pokonanie głębokich, dziedziczonych od dawna podziałów było bardzo trudne. Trudniejsze niż nowe konflikty wynikające z alianckich kar wobec Niemiec, pozornego odizolowania bolszewickiej Rosji, rozpadu wielonarodowych imperiów Europy Wschodniej na liczne, małe państwa narodowe, wreszcie wycofania się Wielkiej Brytanii i Francji w obręb silnie strzeżonych granic swoich kolonialnych imperiów. Dwuznaczna postawa Ameryki - mieszanina ekonomicznego zaangażowania i politycznego wycofania - tylko potęgowała europejski zamęt.

W tych warunkach europejskie przedsiębiorstwa zostały postawione w trudnej sytuacji. Z jednej strony, amerykańskie korporacje wyraźnie wspierały wizję przyszłości Europy jako wschodzącego rynku. Działo się tak przynajmniej do czasu Wielkiej Depresji, podczas której wiele z tych firm wycofało się ze swoich zagranicznych przedsięwzięć. Producenci artykułów trwałego użytku i wyposażenia biurowego, tak jak i filmów, wyobrażali sobie Europę od Londynu i Rotterdamu przez Barcelonę i Bukareszt, aż do Aleksandrii w Egipcie. Podobną perspektywę, ze swoimi attaché handlowymi i rozległą siatką kontaktów, prezentował amerykański Departament Handlu ${ }^{11}$. Przysłowiowy amerykański biznesmen był albo (w optyce amerykańskich pisarzy i filmowców) wizjonerem w typie Sama Dodswortha, albo (z punktu widzenia Europejczyków) nieokrzesanym oportunistą, lekceważącym na przykład subtelności kultury francuskiej, z irytacją powtarzającym „nie zawracaj mi głowy takimi szczegółami”. Z drugiej strony niektóre z najbardziej konkurencyjnych przedsiębiorstw europejskich poszukiwały sojuszów z amerykańskim przemysłem, chcąc wedrzeć się na rynek amerykański albo skorzystać z jego zagranicznej ekspansji. Tą drogą podążał nawet niemiecki magnat medialny o jawnie nacjonalistycznych poglądach, Alfred Hugenberg. Po przejęciu sterów Ufy w 1927 roku ten weimarski samozwańczy car telekomunikacji ponownie zatrudnił w koncernie Pommera. Hugenberg miał nadzieję, że ten przyniesie ze sobą swoje hollywoodzkie doświadczenia w tworzeniu filmów pod gusta międzynarodowego konsumenta i wykorzysta je w eksporcie niemieckiej

${ }^{10}$ Cyt. za M. Argentieri, L'asse cinematografico Roma-Berlino, Libreria Sapere: Neapol 1986, s. 30. Na temat sylwetki Pommera zob. U. Hardt, Erich Pommer: Film Producer for Germany, University of California Press: Los Angeles 1993.

${ }_{11}$ Zob. M. Wilkins, F. E. Hill, American Business Abroad: Ford on Six Continents, Wayne State University Press: Detroit 1964. Kulisy państwowych strategii handlowych odsłaniają przeróżne dokumenty attaché Departamentu Handlu, stacjonujących w Europie od 1921 do 1941, znajdujące się w National Archives, Department of Commerce, Bureau of Foreign and Domestic Trade F. 151. Na temat strategii jednego z głównych amerykańskich reklamodawców, J. Waltera Thompsona, zob. V. de Grazia, The Arts of Purchase: How American Publicity Subverted the European Poster 1920-1940, [w:] Remaking History, „DIA Art Foundation: Discussions in Contemporary Culture”, No. 4, Bay Press: Seattle 1989, s. 221-257. 
produkcji na rynki międzynarodowe oraz - co najbardziej pożądane - że dzięki swoim amerykańskim kontaktom pomoże w wejściu na nieprzyjazny i silnie protekcjonistyczny rynek Stanów Zjednoczonych ${ }^{12}$.

W czasie Wielkiej Depresji amerykańscy biznesmeni zrezygnowali ze swoich władczych zapędów, zaś państwa europejskie podniosły cła, by chronić swoje niestabilne waluty oraz płytkie rodzime rynki. Od wczesnych lat 30 . wzmogły się ze strony europejskich przedsiębiorców, zwłaszcza niemieckich, poszukiwania bardziej ochronnego modelu dla regionalnego przemysłu filmowego. Zyskały one także znaczący wymiar kulturowy wraz z rosnącą popularnością faszystowskiego nacjonalizmu i protekcjonizmu ekonomicznego oraz pojawieniem się produkcji dźwiękowych, które stworzyły nową przestrzeń dla twórczości kinematografii narodowych ${ }^{13}$.

Z punktu widzenia wpływu kulturowego i potencjału ekonomicznego Niemcy pozostawały państwem najlepiej przygotowanym do przewodzenia. Populacja niemieckojęzyczna w Europie wynosiła około 80 milionów ludzi, z szerokimi wpływami także w Europie Środkowej i Wschodniej, gdzie niemiecka kultura i technika cieszyła się wielkim prestiżem. Niemcy były w stanie samodzielnie - dzięki wielkiemu, zintegrowanemu konglomeratowi, jakim była Ufa - wywierać swoim przemysłem filmowym silny wpływ na całą Europę. Co więcej, niemieccy nacjonaliści chwalili kino nie tylko za jego wartości rozrywkowe i propagandowe, ale także za zdolność do kreatywnego wyrażania supremacji Niemiec jako Kulturnation. Poza tym niemiecki przemysł faktycznie pełnił już wtedy rolę unifikującą, z Berlinem jako centrum bogatej, środkowoeuropejskiej kultury filmowej, przyciągającym reżyserów, aktorów i techników z całej Europy Środkowej. Począwszy od 1930 inicjowane przez Niemcy porozumienia monopolistyczne wspomogły między innymi słabnące francuskie firmy dystrybucyjne i zaopatrzeniowe, by mogły ponownie skutecznie konkurować na rynku europejskim ${ }^{14}$.

W następstwie objęcia przez Hitlera funkcji kanclerza w lutym 1933 roku, gdy nazistowscy przywódcy rozpoczynają okres niemieckiego revanche, przemysł filmowy podjął kroki formalne w celu konsolidacji wpływów. Pierwszym ruchem było przekonanie decydentów pozostałych kinematografii narodowych do zin-

12 Zob. T. J. Saunders, Hollywood in Berlin, s. 89 i nast., zwłaszcza s. 90.

13 R. Maltby, R. Vasey, The International Language Problem: European Reactions to Hollywood Conversion to Sound, [w: ] Hollywood in Europe: Experiences of a Cultural Hegemony, eds. D. Ellwood, R. Kroes, VU Press: Amsterdam 1994.

14 Wśród ostatnich tekstów na temat niemieckiego kina w okresie międzywojennym (zwłaszcza w latach 30.) zob. K. Kreimeier, Die Ufa-Story: Geschichte eines Filmkonzern, Hanser: Munich-Vienna 1992; A. M. Rabenalt, Joseph Goebbels und der „Grossdeutsche" Film, Herbig: Munich 1985; E. Rentschler, German Feature Films, 1933-1945, „Monatshefte” 1990, Vol. 82, No. 3, s. 257-266. 
tegrowania przemysłu pionowo, na wzór niemiecki (modelem było SPIO) - by przeciwdziałać wpływom Hollywood's Motion Pictures Producers' and Distributors' Assocation (MPPDA). W 1935 roku podczas Festiwalu Filmowego $\mathrm{w}$ Wenecji przedstawiciele rozlicznych środowisk europejskiego filmu utworzyli - z niemieckiej inicjatywy - International Film Chamber (IFC). Skład członkowski organizacji był międzynarodowy - na liście dwudziestu czterech członków były między innymi Indie oraz Japonia - najwięksi producenci filmowi tamtego czasu. Główne cele IFC miały jednak przede wszystkim charakter kontynentalny: pierwszy prezes, Fritz Scheuemann, był również prezydentem niemieckiego Reichsfilmkammer, wiceprezesem zaś był Giuseppe Volpi di Misurata, założyciel Festiwalu Filmowego w Wenecji i lobbujący w kuluarach za ideą włoskiej „przestrzeni życiowej" (spazio vitale - włoski odpowiednik nazistowskiej Lebensraum) na Bałkanach. IFC skusiło również Francję, organizując w 1937 roku w Paryżu spotkanie, podczas którego to właśnie Francuzowi zaoferowano stanowisko kolejnego prezesa IFC. Włosi natomiast, z uwagi na słabość swojego przemysłu filmowego, próbowali zredukować antyamerykańskie uprzedzenia IFC. Mimo to, przedstawiciele amerykańskiego handlu, ze swoimi brytyjskimi sojusznikami byli wyczuleni na zagrożenie ze strony niemieckiej Ententy. W rezultacie doszło ze strony Amerykanów i Brytyjczyków do bojkotu spotkania w Paryżu, a także wszystkich kolejnych ${ }^{15}$.

Nie jest jasne, czy IFC od początku zakładało jakąkolwiek kulturową misyjność europejskiego filmu. W latach 20. twórcy filmowi i krytycy byli sceptyczni co do tego, czy jakakolwiek europejska produkcja mogłaby stać się taką samą marką jak utwory hollywoodzkie. Próby pisania scenariuszy łączących niemieckich odtwórców głównych ról i francuskie wokalistki (chanteuses) z austriackimi komikami, amerykańskimi ingénues i włoskimi wampami były zaś wyśmiewane jako sztuczny i pozorny kosmopolityzm ${ }^{16}$. Natomiast gdy burżuazyjna Europa w późnych latach 30. skręciła ostro w kierunku nacjonalizmu, wielu ludzi kultury zaczęło - w obliczu amerykańskiego i bolszewickiego materializmu - przychylnie patrzyć na faszystowską ideę „trzeciej drogi”, mającej doprowadzić do odnowy cywilizacji europejskiej. W tej atmosferze propagatorzy kina europejskiego - a przynajmniej ci, którzy uczęszczali na wenecki festiwal i brali udział w ceremoniach rozdania nagród, zdominowanych przez Niemcy i Włochy - wydawali się ulegać opinii o kulturowym, a nie tylko ekonomicznym, wymiarze europejskiego kina.

Dopiero po wybuchu II wojny światowej i zastosowaniu na szeroką skalę niemieckich praw rasowych tego typu głosy rozległy się także w innych państwach narodowych, konkretyzując etniczno-polityczną naturę tej wersji europejskości. Według relacji Vittorio Mussoliniego, syna Duce, któremu powierzono obowiązki

${ }_{15}$ M. Argientieri, L'asse cinematografico..., s. 30-36.

16 V. de Grazia, Cinema and Sovereignity..., s. 74-75. 
w zakresie kultury filmowej i w przemyśle kinematograficznym, europejscy widzowie byli bardzo wdzięczni, że kino zostało „wyrwane z rąk żydowskiej finansjery i ich masońskich sługusów”. Cytując dalej: „Gdy [kino] zostało uformowane na nowo za sprawą europejskiej ogłady”, otrzymało „antidotum na żydowską truciznę, [która] subtelnie fałszowała historię, rozluźniała moralność i obyczaje [oraz] z premedytacją szerzyła mylne interpretacje pojęcia dobra i zła”" ${ }^{17}$.

Trudno wyobrazić sobie sukces tego, zdominowanego przez Niemcy, europejskiego bloku bez wykluczenia z rynku filmów amerykańskich. Jasno pokazują to liczby - całkowita produkcja hollywoodzka wynosiła w 1939 roku pięćset dwadzieścia siedem filmów, w porównaniu do tylko stu sześćdziesięciu wyprodukowanych łącznie przez Niemcy i Włochy ${ }^{18}$. Sytuacja zmieniła się gwałtownie po 1940 roku, gdy Niemcy przez podboje i sojusze rozciągnęly swoją kontrolę na całą Europę. Wtedy to niemiecki przemysł filmowy, z rozkazu Goebbelsa, zaczął reorganizować lokalne kinematografie państw podbitych przez III Rzeszę. To, wraz z czynnikami ekonomicznymi i militarnymi oraz ideologią i polityką rasową spowodowało anihilację przemysłu filmowego w niektórych krajach, a rozkwit innych. Po zajęciu Polski niemiecki rząd okupacyjny praktycznie unicestwił polskie kino. Po 1938 roku, w odwecie za antyniemieckie kwoty wyborcze lat 30., nazistowscy okupanci zredukowali czeską produkcję do 20 procent poziomu przedwojennego. Eksterminacja rasowa wyniszczyła żywiołową kulturę filmową żydowskiej społeczności Europy Wschodniej. Jednocześnie zaś, niemiecki Nowy Porządek stymulował narodziny kin narodowych Chorwacji, Słowenii, Słowacji, Bułgarii i Rumunii oraz zdecydowanie zwiększył witalność kinematografii włoskiej, węgierskiej i francuskiej.

Paradygmatyczny jest przypadek francuski, analizowany przez Evelyn Ehrlich ${ }^{19}$. Zreorganizowany na wzór scentralizowanego modelu włoskiego i pod protekcją UFI (gigant składający się z Ufy oraz innych, niemieckich i zagranicznych koncernów), z olbrzymim zastrzykiem niemieckiego kapitału, francuski przemysł filmowy wyprodukował w ciągu czterech lat okupacji dwieście dwadzieścia filmów pełnometrażowych. Co więcej, wielu obserwatorów twierdziło, że francuskie kino doświadczyło również „rozkwitu kulturalnego”. Początkowo niemieccy nadzorcy nie byli pewni, czy nie należałoby ograniczyć możliwości francuskich filmowców tylko do produkcji przeciętnych, jak ujął to Goebbels, „lekkich, banalnych i, jeśli to możliwe, oklepanych obrazów” na potrzeby konsumpcji wewnętrznej ${ }^{20}$. Ostatecznie zdecydowano o wykorzystaniu francuskie-

17 M. Argientieri, L'asse cinematografico, s. 16.

18 Ibidem, s. 20-21.

19 E. Ehrlich, Cinema of Paradox: French Filmmaking under the German Occupation, Columbia University Press: New York 1985.

20 Ibidem, s. 80. 
go przemysłu jako źródła produkcji wysokiej klasy filmów na eksport przez sieci dystrybucyjne UFI. Powodzenie tej strategii polegało na całkowitym wykluczeniu z rynku filmów amerykańskich. Zakładała ona również wywłaszczenie sieci dystrybucyjnych należących do osób pochodzenia żydowskiego, co przyczyniło się do powstania oligopolistycznej struktury i redukcji liczby produkcji z czterystu dziesięciu w 1939 roku do czterdziestu dwóch w roku 1942. Struktura ta wraz z tanią siłą roboczą, zakazem podwójnych seansów, brakiem alternatywnych rozrywek (co spowodowało gwałtowny wzrost liczby kinowej publiczności) oraz niemieckim systemem luźnej cenzury stworzyły idealne warunki do budowy tego, co miejscowi zwolennicy francuskiego przemyslu postrzegali jako prawdziwe „kino narodów”.

Krytycy omawianego systemu organizacji przemysłu filmowego w czasach nazistowskiego Nowego Porządku (który zasługuje na dokładniejsze zbadanie przy wykorzystaniu udostępnionych niedawno dokumentów) zwracają niekiedy uwagę, że był on tworem całkowicie sztucznym, powołanym do istnienia siłą przez władze nazistowskie i bez szans na przetrwanie pod naporem amerykańskiej konkurencji. Jego działanie faktycznie nie byłoby możliwe bez wykluczenia amerykańskiej produkcji. Niemniej zarządcy UFI, wraz ze swoim przełożonym, ministrem propagandy i oświecenia publicznego Josephem Goebbelsem, doskonale wiedzieli, że widzów nie da się zmusić do uczęszczania na pokazy filmowe. Kinematografia funkcjonowała według zasad biznesowych, mając na uwadze gusta publiczności. W związku z tym zdecydowana większość filmów miała charakter eskapistyczny. Robienie interesów pod zwierzchnictwem agresora trudno jednak określić jako zwyczajny biznes. Konfiskaty mienia żydowskiego można przecież określić jako co najmniej niesprawiedliwe praktyki biznesowe. Niemniej w poszukiwaniach genealogii francuskiego kina narodowego tego typu okoliczności wydawały się nieistotne, przynajmniej dla tych, którzy zachwycali się renesansem francuskiego kina za rządów Vichy.

Czy nazistowskie rządy byłyby w stanie długo tolerować wewnętrzne napięcie między wytwarzaniem produktów dopasowanych do potrzeb rynku a promocją nacjonalistycznego (a nie zaledwie narodowego) kina służącego legitymizacji Trzeciej Rzeszy, wydaje się mało prawdopodobne. Podobnie jak niemożliwe okazało się - gdy wojna była już prawie przegrana - uniknięcie splądrowania państw satelickich i niedawnych sojuszników. W Stanach Zjednoczonych problem „denacjonalizacji” rodzimych produktów kulturowych na potrzeby eksportu rozwiązał się w niejako sam - przemysł filmowy wchłonął pracowników i tematy z ogromnej grupy imigrantów, a krajowa publiczność była bardziej etnicznie różnorodna i przy tym mniej społecznie rozwarstwiona niż europejska. Co więcej, Hollywood nie rościło sobie pretensji do bycia Kultur w głębokim, niemieckim sensie tego słowa. Ostatecznym testem jakości danej produkcji była popularność, jaką cieszyła się na rynku i jej bilans handlowy. 
Walka aliantów z zamkniętymi, imperialistycznymi systemami europejskimi tylko potwierdzała tę wizję. W okresie międzywojennym amerykańscy producenci filmowi, wraz z rządowymi propagatorami handlu zagranicznego, lansowali ideę handlu podążającego za filmem, per analogiam do handlu podążającego za flagą. Innymi słowy, amerykański styl życia miał być promowany przez pobudzanie handlu dobrami pokazywanymi w filmach ${ }^{21}$. Zwycięstwo w wojnie szło w parze $\mathrm{z}$ wygraną Hollywood - amerykańskie wytwory medialne traktowane były jako coś, co posiada immanentną wartość kulturalną. Misja Hollywood od tego momentu przekraczała promowanie stylu życia opartego na dobrach matarialnych. Kinematografia amerykańska nie musiała już walczyć z kinematografiami zamkniętych systemów gospodarczych. Ta „wroga” kinematografia była z definicji kulturowo gorsza - nie z powodu swojego skażenia totalitaryzmem, ale braku ewaluacji rynku i opinii publicznej. Cechą charakterystyczną „wolnego świata” wyzwolonego przez wojska alianckie był swobodny przepływ dóbr, nie tylko kulturowych. Jakakolwiek była natura danego „dobra” ( bez znaczenia czy była to coca-cola, wystawa sztuki ekspresjonistycznej, czy magazyn „Readers' Digest”), cyrkulacja towarów nie tylko umożliwiała kontakty międzyludzkie, ale i istotnie przyczyniała się przez wystawianie zastygłych wspólnot lokalnych na kontakt z nowymi prądami kultury masowej - do prawdziwego kulturowego postępu. Dlatego też amerykański przemysł uznawał za uzasadnione, zarówno ze względów kulturowych, jak i ekonomicznych, używanie siły ( $w$ tym również agencji rządowych) w wywieraniu presji na państwa, które nie chciały otworzyć swoich rynków ${ }^{22}$.

21 Stanowisko to prezentuje najlepiej Review of Foreign Film Markets during 1938, US Bureau of Foreign and Domestic Commerce, Washington, D.C. 1939.

${ }^{22} \mathrm{~W}$ trakcie zimnej wojny wsparcie $\mathrm{w}$ forsowaniu wolnorynkowych zasad opierało się na potężnej mobilizacji instytucjonalnej Stanów Zjednoczonych w kwestiach kulturowych. Przejawiała się ona nie tylko w zleceniu słynnej agencji J. Waltera Thompsona kampanii reklamowej Planu Marshalla, ale również w przedsięwzięciach mniej oficjalnych, służących promocji amerykańskiego stylu życia, od Kongresu Wolności Kulturalnej do samoobsługowych supermarketów. Ostatecznie jednak względy polityczne zadecydowały o wycofaniu się z dogmatycznych pozycji wolnorynkowych przez Amerykanów. Porozumienie Blum-Byrnes, traktowane jako przykład sprzedania się Stanom Zjednoczonym, zostało zreinterpretowane by podkreślić ustępstwa ze strony USA na rzecz utrzymania społecznego spokoju i odsunięcia widma inspirowanych przez komunistów protestów przeciwko zniesieniu regulacji protekcjonistycznych. Zob. J.-P. Jeancolas, w: Hollywood and Europe: Economics, Culture and National Identity 1945-95, eds. G. Nowell-Smith, S. Ricci, British Film Institute/ UCLA: London 1998, oraz J. Portes, Les Origines de la legende noire des accords Blum-Byrnes sur le cinema, „Revue d'Histoire Moderne et Contemporaine” 1986, Vol. XVIII, April-June, s. 314-329. Innymi słowy, amerykański rząd zrozumiał, że forsowanie reguł wolnorynkowych, stojących w sprzeczności z lokalnymi tożsamościami i przemysłem, mogło się okazać przeciwskuteczne i zwiększyć popularność komunistycznych ruchów protestu. 


\section{Europa państw narodowych}

Lata 60. - dwie dekady po tym, jak europejskie społeczeństwa zostały podzielone, a następnie scalone pod przewodnictwem nowych supermocarstw - charakteryzuje zupełnie inny scenariusz. Na Zachodzie wciąż dominujący był model amerykański, ze swoim naciskiem na otwarte rynki, masową konsumpcję i konserwatywną wizją demokracji. Ale jego wpływ, w obliczu spadającej produktywności rodzimej gospodarki, wojny w Wietnamie oraz dążenia państw europejskich do większej niezależności (których wyrazem był zarówno Wielki Plan de Gaulle'a, otwarcie na Europę Wschodnią, jak i Ostpolitik Willy'ego Brandta), wyraźnie malał. Lata 60. były czasem nadziei i trwogi dla kina Europy Zachodniej. Frekwencja kinowa znajdowała się pod wyraźną presją ze strony telewizji, mimo to była wciąż relatywnie duża, szczególnie w Europie Południowej. Jednocześnie, dzięki młodej generacji utalentowanych twórców, ożywiła się kultura filmowa. Do tego, przez swoją sztywną strukturę, w kłopotach znalazło się Hollywood, nie radząc sobie z konkurencją telewizji, wysokimi kosztami produkcji i zmianą gustów. Te okoliczności dawały nadzieję na nową szansę dla europejskiego przemysłu filmowego - i faktycznie, lata 60. to czas wzrostu liczby produkcji we Francji i Włoszech. Był to jednak trend trudny do utrzymania nawet siłami wspólnej europejskiej strategii. Nie wpłynął również na skonstruowanie nowej, trwalszej europejskiej tożsamości kulturowej.

Główna przeszkoda wynikała z samej natury powojennej, europejskiej wspólnoty. Polegała ona zarówno na większym interwencjonizmie poszczególnych rządów w polityce wewnętrznej, jak i większych, wzajemnych podobieństwach europejskich społeczeństw. Mówiło się, że państwa europejskie, na czele z Francją i RFN, zrzekły się części swoich państwowych praw i suwerenności na rzecz tworzenia podstawy do trwałej współpracy międzypaństwowej. Jednak obecnie jeden z głównych historyków europejskiego procesu zjednoczeniowego, Alan Milward, przekonuje, że delegowanie niektórych procesów decyzyjnych (dotyczących polityki handlowej i surowcowej) na rzecz Europejskiej Wspólnoty Gospodarczej służyło $\mathrm{w}$ istocie wzmocnieniu suwerenności ${ }^{23}$. Wyjaśniałoby to wytrwałość protekcjonistów i partykularystyczną legislację, zdecydowanie większą spójność wewnętrzną państw europejskich oraz rozbieżności polityczne lat 70., wraz z osłabieniem się międzynarodowej ekonomii i kryzysem naftowym. Podkreślając suwerenność wraz z implikowaną przez nią autonomią i odrębnością, nie można jednak zapominać o postępującej wspólnotowości. Na początku lat 60. społeczeństwa europejskie były już o wiele mocniej złączone globalnymi powiązaniami i rozbudowanymi rządowymi regulacjami. W tym sensie byly

23 A. Milward, The European Rescue of The Nation-State, University of California Press: Berkeley 1992. 
silniejsze jako państwa narodowe. $Z$ drugiej strony te symultanicznie zachodzące zmiany, następujące w wyniku szerokiej odpowiedzi na rozszerzanie się rynków pod egidą Stanów Zjednoczonych, zimnowojennych podziałów oraz wzrostu gospodarczego, doprowadziły do zbliżenia się europejskich społeczeństw.

Kładąc nacisk na „suwerenność” i „konwergencję”, możemy lepiej wytłumaczyć znaczenie polityki kulturalnej tamtego okresu, zwłaszcza dotyczącej kinematografii. Państwa członkowskie EWG cechował brak jakiejkolwiek wspólnej polityki kulturalnej. Jest to zrozumiale, jeśli weźmiemy pod uwagę względy historyczne. Ci wszyscy, którzy przypisują dziś Jeanowi Monnetowi znaną sentencję: „gdybym zaczynał to [tj. proces zjednoczeniowy] dziś, rozpocząłbym od kultury" - zapominają, że narody Europy musiały najpierw odzyskać siły po wyczerpującej wojnie i okupacji zanim mogły podjąć próby zjednoczenia. Mając to na uwadze, należy nadmienić, że państwa EWG mimo wszystko tworzyły programy o znaczących konsekwencjach kulturalnych. Można wymienić cztery, związane bezpośrednio $\mathrm{z}$ kinem. W ramach pierwszego, mającego za zadanie ułatwienie handlu między krajami Szóstki, zdefiniowano pojęcie "narodowy” w kontekście przemysłu. W przypadku kina definicja musiała być na tyle szeroka, by móc objąć koprodukcje. Oznaczało to uznanie wszystkich firm utworzonych zgodnie z powszechnie obowiązującym prawem. Nieuchronne było pojawienie się wśród przedsiębiorstw krajowych takich, które w przeważającej liczbie były finansowane przez Stany Zjednoczone. Drugi polegal na milczącym przyzwoleniu krajów EWG na otoczenie lokalnych przemysłów filmowych opieką (również finansową), jednak bez jasnego określenia jej natury. Była ona oferowana ze względów ekonomicznych, takich jak utrzymanie zatrudnienia czy strategiczna rozbudowa tej gałęzi gospodarki, czy też może ze względów kulturowych. Trzeci wiązał się z faktem, że telewizja była traktowana jako usługa publiczna, narzędzie powszechnej edukacji oraz sposób kontrolowania przepływu informacji. Również tu doszło do milczącego porozumienia: zdecydowano się podzielić sektor audiowizualny według dwóch modeli: przemysł filmowy miał być organizowany według modelu rynkowego, podczas gdy telewizja była objęta państwowym monopolem. Podział ten powstrzymał państwa członkowskie przed stworzeniem wszechstronnej, kompletnej polityki audiowizualnej - czy to na poziomie narodowym, czy ponadnarodowym. Konsekwencją ostatniego było wspólne przekonanie, że nowoczesna gospodarka zrodzi nowy, ponadnarodowy system wartości.

Opisywany system ekonomiczny, jeśli można tak go nazwać, bazował na swoistej logice: teoretycznie otwarty, a jednak protekcjonistyczny, służył integrowaniu europejskich społeczeństw wokół wspólnej kultury materialnej, jednocześnie przysługując się rządowym wysiłkom na rzecz większej autonomii i niezależności od słabnącej wtedy amerykańskiej hegemonii. Osiągnięcia w dziedzinie światowego kina wpisują się w powyższy kontekst. Do połowy lat 60. dziewięć państw tworzących ówczesne EWG mogło się pochwalić publicznością i możliwościami produkcyjnymi większymi od amerykańskich. Dzięki znacznym in- 
westycjom w przemysł filmowy nastąpił wzrost liczby produkcji, a w przypadku Francji i Włoch doszło również do restrukturyzacji sektora na wzór amerykański. Wzrostowi ekonomicznemu towarzyszył niesłychany rozwój artystyczny będący skutkiem pojawienia się zarówno nowej generacji twórców wychowanych na kulturze filmowej Europy i Stanów Zjednoczonych, jak i z licznego grona widzów urodzonych po wojnie (często o sympatiach lewicujących) i nowych ruchów społecznych lat 60. i 70., na które wpływ miały gwałtowne przemiany w sferze norm społecznych, seksualnych i kulturowych.

Problemem tego „europejskiego” rozwoju było to, że w rzeczywistości miał niewiele wspólnego z Europą, czy to pod względem źródeł finansowania, czy też w perspektywie jego głównych aktorów. Najmniej zaś był on „europejski” w oczach samej widowni (o ile możemy w ogóle zakładać wiedzę na temat jej poglądów).

Europejski boom filmowy doby lat 60 . faktycznie był ściśle związany z kryzysem roli Stanów Zjednoczonych. Na globalnym rynku pozycja dolara była przeszacowana, podczas gdy - ze względu na ulgi podatkowe na zagraniczne inwestycje - następował odpływ kapitału ze Stanów Zjednoczonych. W porównaniu ze zniedołężniałym systemem studyjnym w Hollywood, kino europejskie było, dzięki niskim kosztom pracy, licznym talentom i wciąż dużemu rynkowi konsumenckiemu, rajem dla inwestorów. Co najważniejsze, jeśli inwestorzy ze Stanów zdecydowali się na założenie firmy w Europie, stając się częścią lokalnego rynku, mogli korzystać z tych samych ulg podatkowych i chroniło ich to samo prawo handlowe, co miejscowe przedsiębiorstwa. Jednocześnie jednak obecność amerykańskich firm w Europie doprowadziła do nadużyć. Na ogół zawyżały one koszty produkcji, co więcej - starały się omijać związki zawodowe. W końcu, gdy spadła frekwencja kinowa, wzrosła inflacja i doszło do dewaluacji dolara, Amerykanie wycofali swoje inwestycje, pogrążając lokalne rynki ${ }^{24}$.

$\mathrm{Ci}$, którzy poszukiwali wspólnej definicji europejskiej kultury mieli w tych warunkach nie lada orzech do zgryzienia. W odniesieniu do starych pretensji Europy do reprezentowania uniwersalistycznej, unifikującej kultury, tylko Francja

${ }^{24}$ Zob. bardzo ważny tekst T. H. Guback, Cultural Identity and Film in the European Economic Community, „Cinema Journal” 1974, Vol. XIV, No. 1, Fall. Zob. też idem, The International Film Industry, Indiana University Press: Bloomington 1969. W osobistej rozmowie Heide Fehrenbach sugerowała, że przemysł Niemiec Zachodnich podążał inną drogą. Zob. również H. Fehrenbach, Cinema in Democratizing Germany: Reconstructing National Identity after Hitler, University of North Carolina Press: Chapel Hill 1995. Na temat finansowania produkcji filmowych zob. E. Monaco, The Financing of Film Production in Europe, „Cinema Journal” 1974, Vol. XIV, No. 1, Fall, s. 18-25.Odnośnie do zbieżności stylistycznych i ekonomicznych między amerykańską i europejską twórczością filmową, zob. P. Lev, The Euro-American Cinema, University of Texas Press: Austin 1993. 
i jej kulturalny establishment wytrwali w tym zadaniu. Pod przewodnictwem de Gaulle’a i ówczesnego ministra świeżo powołanego Ministerstwa Kultury, André Malraux, francuscy intelektualiści wypowiadali się jako rzecznicy „cywilizacji europejskiej”. W przeciwieństwie do niemieckiego Kulturnation - wykluczającego, rasistowskiego i irracjonalnego - wizja francuska była uniwersalistyczna i racjonalna. Przewidywała ona współpracę oświeconej, państwowej biurokracji z siłami rynkowymi, mającą na celu ochronę i promocję kina oraz innych sfer kultury wysokiej. Lewica, równie eurocentryczna w swych założeniach, choć o innych intencjach, chciała stworzenia kultury internacjonalistycznej, takiej, która sprzymierzyłaby się z amerykańską kulturą popularną, marksizmem oraz trzecioświatowym populizmem, która rzuciłaby wyzwanie hierarchicznej, autorytarnej i rasistowskiej kulturze starej Europy. Być może jedyną tego typu jednoczącą siłą kulturową, o ile można ją nazwać „europejską”, była międzynarodowa kultura młodzieżowa, która - choć wywodziła się z USA - rozwinęła się w latach 60. za sprawą europejskich zespołów popowych i rockowych ${ }^{25}$. Napędzana powszechnym, konsumpcjonistycznym stylem życia wywodzącym się z lat boomu gospodarczego przebyła całą Europę, od Liverpoolu do Leningradu, podważając tradycyjne rozumienie narodowych granic i przynależności. Można powiedzieć, że stworzyła nowy typ tożsamości euroamerykańskiej, niemieszczącej się w żadnych ówczesnych ramach politycznych.

Podsumowując sytuację z lat 60., należy stwierdzić, że nie było wtedy żadnej wspólnej wizji europejskiej kultury, poza tą definiowaną terminami ekonomicznymi. Amerykańska przewaga technologiczna stanowiła wyzwanie dla Europy, która w widoczny sposób próbowała jej dorównać. Wzywając rządy państw europejskich do podjęcia rękawicy, Jean-Jaques Servan Schreiber wykształcił projekt dynamizacji rozwoju na polu komunikacyjnym z towarzyszącymi mu ogólnymi reformami systemu edukacji i zwiększonymi inwestycjami w sfery badań i projektowania ${ }^{26}$.

\section{W kierunku Europy wielokulturowej?}

Niedawne badania wskazały, że obecny nacisk na jedność Europy nie wynika $\mathrm{z}$ sukcesu poprzednich tego typu starań, ale z porażki projektów opartych na unifikacji ekonomicznej w starciu z nową fazą globalizacji światowej gospodarki.

25 O internacjonalizmie kultury młodzieżowej, stymulowanej trendami amerykańskimi, zob. artykuły A. Portelli, F. Minganti, K. Maase, M. van Elteren, S. Fox, R. Kroes, w: Cultural Transmissions and Receptions, ed. R. Kroes [i in.], oraz T. Ryback, Rock around the Bloc: A History of Rock Music in Eastern Europe and the Soviet Union, Oxford University Press: New York 1990.

26 The American Challenge, Atheneum: New York 1968. 
By przeciwdziałać odśrodkowym tendencjom państw Europy Zachodniej, które próbowały indywidualnie reagować na kryzys naftowy lat 70., konwergencja wymagała pełniejszej integracji gospodarczej. Mogła ona odnieść sukces jednak tylko wtedy, gdyby decydenci polityczni dostrzegli konieczność promowania integracji na wszystkich poziomach, także kulturowym ${ }^{27}$. W obliczu dochodzących do głosu lokalnych partykularyzmów towarzyszących restrukturyzacji globalnej ekonomii, rozpadu bloku sowieckiego i szybkiego wzrostu liczby państw narodowych i mniejszości etnicznych oraz migracji, a także ogromnego oporu w obrębie samej Europy, wymiar kulturowy integracji zyskał jeszcze większe znaczenie. W tych okolicznościach powiązania stworzone przez europejski przemysł audiowizualny - $\mathrm{w}$ wymiarze komunikacyjnym, informacyjnym i kulturalnym - wydawały się kluczowe dla budowania wspólnej tożsamości. Obserwacji tej towarzyszyły jednak dwa pesymistyczne spostrzeżenia. Po pierwsze, reorganizacja rynku pociągnęla za sobą niezwykle wysokie koszty ludzkie (w postaci cięć socjalnych, wysokiej migracji, bezrobocia i silnej segmentacji siły roboczej) - te zaś przyczyniły się do zwielokrotnienia i fragmentacji tożsamości. Po drugie, uświadomiono sobie, że nawet zjednoczona Europa nie ma łatwej kontroli nad przestrzenią audiowizualną, ponieważ jest zdominowana z zewnątrz. Powyższa argumentacja prowadzi więc do wniosku, że Europejczycy pozbawieni są tego, czego najbardziej potrzebują, by pokonać obecny kryzys tożsamości i obdarzyć zaufaniem instytucje europejskie ${ }^{28}$.

Kino europejskie, niebędące współcześnie znaczącym graczem na obszernym medialnym rynku, dobrze symbolizuje powyższe dylematy. Żądania ochrony dla kinematografii ze względu na jej „europejskość” są zapowiedzią szerszych wymagań dotyczących ochrony tożsamości jako takich ${ }^{29}$. Zrozumiałe, z wielu powodów, jest również przodownictwo francuskiej kultury i świata filmu. Po pierwsze, francuskie elity posiadają długą tradycję myślenia w kategoriach europejskich; po drugie, ze względu na ugruntowaną pozycję kinematografii (wynikającą między innymi z silnego wsparcia państwa); po trzecie, z popierania ruchów kulturowych

27 G. Ross, Confronting the New Europe, „New Left Review” 1992, Vol. 191, s. 4968; A. Minc, The Great European Illusion, Blackwell: London 1987 - tekst zawiera proroczą analizę wagi kulturowego wymiaru europejskiego procesu zjednoczenia.

${ }_{28}^{28}$ Debaty na ten temat podsumowuje Les Médias face á l’Europe, „Médiaspouvoirs” 1994, janvier-juin, s. 3-34.

${ }^{29}$ Jeśli chodzi o typowy przykład, zob. Ch. Adriani, Pour le cinéma français et le cinéma en France, „La Penseé” 1993, novembre-décembre, Vol. 296. Ważną konkluzję czyni Dominique Wolton, stwierdzając, że o ile w przeszłości tożsamość stanowiła problem w komunikacji, o tyle współcześnie jest w niej czymś niezbędnym - zob. D. Wolton, L'Europe aux risques de la communication, „Médiaspouvoirs” 1994, janvier-juin, s. 63-70. Przegląd kondycji kina oferuje D. Hancock, Cinema in Europe: A Panorama, „Communications et Stratégies" 1992, $2^{\text {me }}$ Trimestre, No. 6, s. 139-153. 
w Europie Środkowo-Wschodniej będących mocnym wsparciem dla idei zjednoczonej Europy (z reguły jako przeciwwagi dla pozycji Rosji); a w końcu - ze względu na słabość francuskich przedsiębiorstw medialnych wobec zakusów potężnych międzynarodowych konglomeratów, przyćmiewanych przez niemieckiego Bertelsmanna czy amerykańskich Time Warner, Disney, Newscorp czy ICI.

Wraz ze wzrostem konkurencyjności oraz mnożeniem się debat na temat europejskiej tożsamości możemy spodziewać się jeszcze więcej dyskusji dotyczących tego, czym Europa powinna być kulturowo. W propozycjach francuskiego przywództwa, albo osi Paryż-Berlin uznającej nowe wpływy Niemiec w Europie Środkowo-Wschodniej i służącej zjednoczeniu gospodarczej potęgi obu państw ( „by utwardzić kręgosłup europejskiego mięczaka”, jak to ujął jeden z francuskich komentatorów), słychać wyraźnie echa przeszłości ${ }^{30}$.

Dylematy dotyczące tożsamości europejskiej nie były i nie są ściśle ograniczone do samej Europy. Obecnie interesy medialne Stanów Zjednoczonych, wspierane przez rządową politykę, stoją za wizją wolnego rynku diametralnie przekształcającego kulturowe i społeczne wartości lokalnych tożsamości. Za presją amerykańskich negocjatorów wywieraną na zniesienie praktyk protekcjonistycznych chroniących kinematografię stoją oczywiście powody ekonomiczne - produkcje filmowe znajdują się na drugim miejscu w rankingu opłacalności eksportowej USA, ustępując jedynie technologiom powietrzno-kosmicznym i produktom rolniczym. Pokonując opór przed uwolnorynkowieniem przemysłu filmowego, Amerykanie chcą również złamać opór w całym ogromnym sektorze rynku medialnego i jego działach: telewizji cyfrowej i kablowej, informacji oraz pozostałych, dynamicznie się rozwijajacych.

Abstrahując od partykularnych interesów ekonomicznych, nowym amerykańskim i europejskim modelom urynkowionego społeczeństwa przyjdzie się znowu zmierzyć. Zgodnie ze scenariuszem Stany Zjednoczone w interesie globalnego rozwoju ponownie proponują model czystego rynku, zaś Europa stoi po stronie „kapitalizmu reńskiego” - gospodarek jeszcze protekcjonistycznych, wciąż rozwijając społeczną wizję rynku i celowości ingerencji państwowej ${ }^{31}$.

Obydwa modele przewidują zupełnie odmienne relacje między rynkiem a kulturą: amerykański, spod znaku ekonomii neoklasycznej, jest wręcz karykaturą obrazu sił rynkowych pustoszących XIX-wieczne społeczeństwo brytyjskie, nakreślonego przez Karla Polanyi'ego ${ }^{32}$. Jego funkcjonowanie przypomina ustawę New Poor Law wymierzoną w arystokratyczne noblesse oblige: rynek będzie prawdziwie wolny tylko wtedy, gdy usunięte zostaną wszelkie pozostałości

30 J.-M. Frodon, Le Cinéma en panne, „Le Monde” 1994, 11 juin.

31 Termin „kapitalizm reński” rozwinął M. Albert, Capitalism vs. Capitalism (Capitalisme contre capitalisme), Whurr Publishers Ltd: London 1993.

32 K. Polanyi, The Great Transformation, Beacon Press: Boston 1985. 
starych instytucji, od fabryk Forda i nieefektywnych sieci dystrybucyjnych po państwowe systemy emerytalne i zdrowotne. Warto zauważyć, że amerykańskie elity biznesowe nie zawsze sympatyzowały z tą perspektywą. W przeszłości rozumiały one, że wszelkim wielkim reformom gospodarczym musiało towarzyszyć - w imię spójności społecznej - zaangażowanie kwestii tożsamości. Dlatego też za każdą większą restrukturyzacją rynku szła społeczna innowacyjność i kampanie na rzecz „amerykańskich wartości”, wyrażanych przez natywizm, ruch przeciw występkowi moralnemu (np. prohibicjonizm) oraz fundamentalizm religijny.

Z punktu widzenia wyrównywania szans sugeruje się Europie (a także Meksykowi i Rosji) coś, czego amerykańskie elity nigdy nie akceptowały na swoim terenie: czystą kartę w perspektywie instytucji i tożsamości ${ }^{33}$. Pamięć historyczna stała się najwyraźniej za krótka, by pamiętać o tym, że za każdą wielką reformą kapitalizmu idzie zachwianie tożsamości kulturowych wraz z towarzyszącymi jej destabilizującymi ideologiami, generującymi nowe społeczne sytuacje i nieprzewidziane zmiany polityki, niosące często katastrofalne konsekwencje dla Europy.

Teraz jednak, inaczej niż w latach 30. i na nowy sposób nawiązując do lat 60., definicja znaczenia „tożsamości” i „kultury europejskiej” jest szczęśliwie wciąż otwarta i podatna na zmiany. Dyskusja nad tym, czy istnieje coś takiego jak kino europejskie jest jak najbardziej uzasadniona, a z pewnością dużo bardziej niż debata na temat kanonicznej europejskiej kultury. Tak samo jak uzasadnione jest zwracanie uwagi na niebezpieczeństwa stojące za wykorzystywaniem tych pojęć w polityce tożsamościowej. Niemniej ruchy dążące do pielęgnacji obfitej, europejskiej przestrzeni kulturowej, w której można eksperymentować z ideami wielokulturowości i innowacyjności, są potrzebne, intrygujące i zasługują na szacunek.

$\mathrm{Z}$ angielskiego przełożył Mateusz Mirys

33 Antagonistyczne stanowiska w tej debacie prezentuje wymiana zdań Regisa Debraya i zwolennika wolnego rynku Mario Vargasa Llosy. Ten ostatni sugeruje, że wolny rynek promuje sobą określone idee, przeciwstawiając otwartość rynku trybalizmowi, neutralność stronniczości, gościnność wrogości i otwartość zamknięciu. Zob. Quelles tribus? Cher Mario, „Libération” 1994, 5 décembre. 